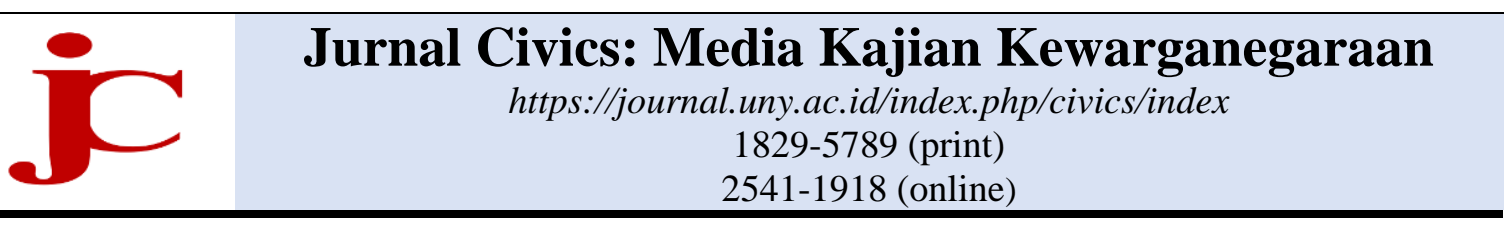

\title{
Kinerja Mahkamah Konstitusi dalam mewujudkan electoral justice pada pemilihan kepala daerah serentak tahun 2017
}

\author{
Halili $^{\text {a, }}{ }^{*}$, Sri Hartini ${ }^{\text {b, }, \text {, Iqbal Arpannudin }}{ }^{\text {c, } 3}$ \\ a,b,c Jurusan Pendidikan Kewarganegaraan dan Hukum, Fakultas Ilmu Sosial, Universitas Negeri Yogyakarta, \\ Sleman, Indonesia \\ ${ }^{1}$ halili.ysu@gmail.com*;2 sri_hartini@uny.ac.id; ${ }^{3}$ arpannudin@uny.ac.id \\ *korespondensi penulis
}

\begin{tabular}{ll}
\hline \multicolumn{2}{l}{ Informasi artikel } \\
\hline Sejarah artikel: & \\
Diterima & $: 31-07-2018$ \\
Revisi & $: 16-08-2018$ \\
Dipublikasikan & $: 31-10-2018$ \\
\hline
\end{tabular}

Kata kunci:

mahkamah konstitusi

electoral justice

kepala daerah

\begin{abstract}
ABSTRAK
Artikel ini bertujuan untuk mendeskripsikan penegakan keadilan prosedural dan substantif dalam peradilan sengketa pemilihan kepala daerah serentak tahun 2017 oleh Mahkamah Konstitusi (MK) Republik Indonesia. Pendekatan yang digunakan adalah kualitatif dengan metode analisis isi. Hasil analisis menunjukkan, pertama, MK sepenuhnya konsisten untuk menjadikan pasal mengenai tenggat waktu pengajuan permohonan dan kedudukan hukum pemohon sebagai batu uji mengenai dapat diterima atau tidaknya sebuah permohonan dalam perkara sengketa pilkada 2017. Hal itu sebagai dampak dari diadopsinya proses dismissal (dismissal process). Kedua, penegakan keadilan prosedural dalam peradilan sengketa pilkada oleh MK tidak secara serta merta in line dengan perwujudan keadilan elektoral yang bersifat substantif. Ada kecenderungan bahwa putusan dismissal yang dilakukan oleh MK cenderung mengabaikan keadilan substantif. Ada dua hal yang potensial membuat prosedur beracara tidak dapat mewujudkan keadilan substantif dalam proses peradilan sengketa Pilkada di MK, yaitu; 1) tenggat waktu yang menyimpang asas nunc pro tunc dan 2) ambang persentase selisih hasil suara dalam sengketa pilkada, yaitu tidak lebih dari $0,5 \%, 1 \%, 1,5 \%$ atau $2 \%$.

\section{ABSTRACT}

This article aims to describe the enforcement of procedural and substantive justice in the 2017 regional head election dispute court by the Republic of Indonesia Constitutional Court (MK). The approach used is qualitative with the content analysis method. The results of the analysis show, first, the Court is fully consistent in making the article regarding the deadline for submitting applications and legal status of the applicant as a test stone regarding whether or not an application can be accepted in a 2017 election dispute case. It is as a result of the dismissal process. Second, the enforcement of procedural justice in the election dispute court by the Constitutional Court is not necessarily in line with the realization of substantive electoral justice. There is a tendency that the decision dismissal carried out by the Constitutional Court tends to ignore substantive justice. There are two things that have the potential to make the procedure of proceedings unable to realize substantive justice in the Pilkada dispute trial process in the Constitutional Court, namely; 1) deadlines that deviate the principle of nunc pro tunc and 2) the threshold of the percentage of the difference in vote results in the election dispute, which is not more than $0.5 \%, 1 \%, 1.5 \%$ or $2 \%$.
\end{abstract}

Keywords:

constitution court

electoral justice

had of district

\section{Copyright $@ 2018$ Halili, dkk}

\section{Pendahuluan}

Pemilihan umum merupakan salah satu ruh demokrasi karena merupakan arena yang sah untuk mengonversi kedaulatan rakyat menjadi otoritas-otoritas politik dan tata pemerintahan oleh institusi-institusi di negara 
demokratis. Dengan demikian, kualitas dan kedalaman demokrasi sebuah negara ditentukan oleh legitimasi politik (kekuasaan) dan integritas pemilunya. Beetham merumuskan tiga prasyarat yang harus dipenuhi dalam sebuah kekuasaan. Pertama, kekuasaan dengan aturan yang disepakati, baik formal maupun informal. Kedua, aturan tersebut harus disepakati antara pemerintah dengan yang diperintah. Ketiga, legitimasi kekuasaan harus ditunjukkan oleh ekspresi persetujuan dari pihak yang diperintah (Heywood, 2013). Dari ketiga prasyarat sahnya kekuasaan tersebut, terdapat dua hal yang menjadi ciri legitimasi yang sah yang dikehendaki dalam proses demokrasi, yakni pertama, adanya pemilihan umum yang merupakan kontestasi partai politik, dan kedua, adanya konstitusi yang mengatur pertarungan legitimasi tersebut.

Pemilihan gubernur, bupati, dan walikota atau disebut juga Pemilihan Kepala Daerah (Pilkada), sebagai bagian dari pemilu, merupakan arena yang sangat menentukan derajat dan kualitas negara demokrasi konstitusional. Meskipun Mahkamah Konstitusi mengeluarkan Pilkada dari rezim Pemilu melalui Putusan MK No. 97/PUUXI/2013, tanggal 16 Januari 2014, secara ontologi Pilkada merupakan bagian dari pemilihan umum, yang dilaksanakan di tingkat lokal untuk memilih kepala-kepala daerah.

Pilkada tidak hanya dilihat sebagai implementasi hak warga negara dan cerminan proses demokrasi saja, namun lebih penting adalah menjamin harapan dan kepercayaan rakyat (Akbar, 2016). Dengan demikian, diperlukan sebuah sistem yang komprehensif yang menjamin Pilkada yang bebas, jujur dan adil dengan prinsip-prinsip demokrasi, sistem hukum yang komprehensif dan ada lembaga yang menangani perselisihan hasil pemilu (Orozco-Henríquez, 2010). Oleh karena itu, maka setiap aspek dan tahapan Pilkada, mulai dari manajemen penyelenggaraan, proses pengelolaan, hingga penyelesaian masalah yang muncul di awal penyelenggaraan, ditengah-tengah proses pemungutan suara, dan pasca pemungutan suara menjadi sangat penting untuk diatur sedemikian rupa untuk menegakkan sistem pemilihan yang lebih baik dan adil. Setiap ketidakpuasan, koreksi, dan complain terhadap penyelenggaraan Pilkada harus mendapatkan ruang penyelesaian demi memberikan keadilan elektoral bagi setiap aktor politik, pemilik suara, maupun massa pendukung dalam Pilkada. Dengan kata lain, untuk menjamin terwujudnya Pilkada yang sesuai dengan prinsip demokrasi, maka seluruh proses harus dilaksanakan dengan baik mulai dari electoral regulation, electoral process, dan electoral law enforcement (Zoelva, 2013).

Dalam konteks Indonesia, ketidakpuasan terhadap proses dan hasil Pilkada sebagian besar berujung pada proses sengketa yudisial. Fungsi mahkamah konstitusi pada tidak terbatas pada pengujian konstitusionalitas suatu undang-undang, akan tetapi juga menyelesaikan masalah terkait pemilihan dan masalah-masalah kenegaraan lainnya (Bass \& Choudhry, 2013). Mahkamah Konstitusi (MK) sebagai lembaga peradilan yang sejak tahun 2008 memiliki kewenangan mengadili sengketa hasil Pilkada selama rentang waktu 2008-2018, MK telah menerima 1016 perkara yang masuk dengan komposisi kabul: 75 tolak: 471 tidak diterima: 400 tarik kembali: 27 gugur: 5, dan jumlah putusan sebanyak 981 putusan (Mahkamah Konstitusi, 2018). Data tersebut menunjukkan betapa penting dan strategisnya peran peradilan sengketa Pilkada. Legitimasi dan integritas Pilkada pada akhirnya tidak hanya ditentukan oleh bagaimana tata kelola penyelenggaraan Pilkada dan proses pemungutan suara dalam Pilkada, akan tetapi juga ditentukan oleh proses peradilan sengketa hasil Pilkada di arena-arena meja hijau yudisial. Oleh karena itu, menjadi sangat penting upaya untuk memastikan ketersediaan mekanisme yudisial yang mandiri, transparan, kredibel, dan berorientasi pada penegakan keadilan substantif bagi setiap pihak yang terlibat dalam Pilkada (electoral justice).

Dalam konteks Pilkada serentak tahap pertama yang sudah dilaksanakan pada bulan Desember tahun 2015, terdapat kemendesakan (sense of urgency) untuk melakukan upaya konkret pelembagaan mekanisme peradilan tertentu berkaitan 
dengan sengketa hasil yang kemungkinan besar terjadi. Diperlukan langkah-langkah cepat untuk membuat lembaga peradilan tersebut, setelah MK menyatakan bahwa Pilkada bukan bagian dari rezim Pemilu yang berarti bahwa peradilan sengketa Pilkada bukan lagi kewenangannya, sementara di sisi lain Undang-Undang Nomor 1 Tahun 2015 tentang Penetapan Peraturan Pemerintah Pengganti Undang-Undang Nomor 1 Tahun 2014 Tentang Pemilihan Gubernur, Bupati, dan Walikota Menjadi Undang-Undang memerintahkan pembentukan badan peradilan sengketa Pilkada yang berbasis di Pengadilan Tinggi untuk menangani sengketa Pilkada. Namun Undang-Undang Nomor 8 Tahun 2015 tentang Perubahan atas Undang-Undang No 1 Tahun 2015 menegaskan hal berbeda. Undang-undang tersebut mengembalikan kewenangan mengadili sengketa hasil Pilkada kepada Mahkamah Konstitusi (MK), meskipun tetap membawa perintah pembentukan badan peradilan khusus.

Pasal 157 Ayat (1) Undang-Undang Nomor 8 Tahun 2015 menyatakan bahwa "perkara perselisihan hasil pemilihan diperiksa dan diadili oleh badan peradilan khusus." Pada ayat selanjutnya di pasal yang sama ditegaskan bahwa, "badan peradilan khusus sebagaimana dimaksud pada ayat (1) dibentuk sebelum pelaksanaan pemilihan serentak nasional." Sedangkan di dalam ayat (3) dinyatakan bahwa "perkara perselisihan penetapan perolehan suara hasil pemilihan diperiksa dan diadili oleh Mahkamah Konstitusi sampai dibentuknya badan peradilan khusus." Ketentuan tersebut mendatangkan minimal dua komplikasi hukum, dan pada akhirnya juga komplikasi politik.

Pertama, inkonsistensi dalam konstitusionalitas kewenangan mengadili sengketa hasil Pilkada. Mahkamah Konstitusi merupakan pengawal dan penguji tunggal konstitusionalitas hukum di Indonesia. Putusan MK sebagaimana kita tahu bersifat final dan mengikat. Melalui Putusan No. 97/PUU-XI/2013, tanggal 16 Januari 2014, MK menyatakan bahwa dirinya tidak (lagi) memiliki kewenangan untuk mengadili sengketa hasil Pilkada dan mengembalikan institusionalisasi kewenangan mengadili sengketa hasil Pilkada tersebut kepada pembentuk undang-undang.

Kedua, kapasitas institusional dan teknis yudisial MK dalam mengadili sengketa Pilkada serentak. Ius constitutum yang memberikan kewenangan kepada MK untuk mengadili sengketa hasil Pilkada tampaknya tidak didasarkan pada simulasi kapasitas teknis yudisial dikaitkan dengan jumlah Pilkada yang akan dilaksanakan secara serentak tersebut dikaitkan dengan variabel waktu yang tersedia. Pada akhirnya, yang menjadi taruhan dalam situasi tersebut adalah keadilan pemilu (electoral justice) dan integritas Pilkada itu sendiri. Sistem electoral justice harus berjalan efektif, serta menunjukkan kemandirian dan tidak memihak untuk mewujudkan keadilan, keterbukaan dan kesetaraan (OrozcoHenríquez, 2010). Bagaimana kinerja MK dalam Peradilan Sengketa Pilkada Serentak untuk mewujudkan keadilan elektoral?

\section{Metode}

Pendekatan kualitatif digunakan untuk menganalisis kinerja Mahkamah Konstitusi untuk mewujudkan electoral justice ini dengan metode content analysis. Penelitian analisis konten merupakan penelitian yang berusaha mengungkap makna simbolik beberapa pesan (Krippendorff, 2004). Mengacu pada klasifikasi Arikunto (2013), maka sumber data yang digunakan dalam penelitian ini berupa dokumen-dokumen primer putusan Mahkamah Konstitusi dalam sidang sengketa Pilkada 2017 dan dokumen sekunder seperti buku dan dokumen-dokumen lain yang memberikan data penunjang atas dokumen primer.

Dalam analisis konten data sudah tersedia dari sumber data tertentu. Dalam penelitian ini data yang dimaksud adalah data berupa putusan Mahkamah Konstitusi yang diunggah oleh Sekretariat Jenderal Mahkamah Konstitusi beberapa menit setelah pembacaan putusan tiap perkara selesai dilaksanakan. Instrumen yang digunakan dalam penelitian ini adalah peneliti sendiri dengan bantuan check list dan recording note. 
Pengujian keabsahan data menggunakan validitas semantik (untuk mengetahui ketepatan dalam mengartikan kata) dan prediktif (untuk mengetahui ketepatan memaknai data yang sudah dikelompokkan secara tematik). Analisis yang digunakan dalam penelitian analisis konten ini adalah analisis deskriptif dan analisis inferensial.

\section{Hasil dan Pembahasan}

Demokrasi dinilai sebagian ilmuwan memiliki kelemahan karena proses dan mekanisme yang ditempuh lebih berdasar atas besar-kecilnya suara atau lemah-kuatnya dukungan. Ketika telah disepakati bahwa Indonesia menggunakan prinsip demokrasi konstitusional (constitutional democracy), maka apapun cara, sistem, dan penerapan berdemokrasinya tentu tidak boleh juga bertentangan dengan konstitusi (Mahfud-MD, 2009). Demikian pula terhadap perkara perselisihan hasil pemilu (Pilkada), perkaraperkara yang masuk, pada umumnya MK melakukan pemeriksaan atas beberapa substansi dalam sengketa atau perselisihan. Pada umumnya pemeriksaan meliputi empat aspek utama:

a) Kewenangan $\mathrm{MK}$ sendiri dalam menangani perkara perselisihan. Dalam memeriksa kompetensi absolut MK ini, para hakim merujuk pada ketentuan Pasal 157 ayat (3) Undang-Undang Nomor 10 Tahun 2016 tentang Perubahan Kedua Atas Undang-Undang Nomor 1 Tahun 2015 tentang Penetapan Peraturan Pemerintah Pengganti Undang-Undang Nomor 1 Tahun 2014 tentang Pemilihan Gubernur, Bupati, dan Walikota Menjadi Undang-Undang. Ketentuan tersebut berbunyi bahwa "perkara perselisihan penetapan perolehan suara tahap akhir hasil pemilihan diperiksa dan diadili oleh Mahkamah Konstitusi sampai dibentuknya badan peradilan khusus". Selain itu MK juga merujuk pada ketentuan Pasal 157 ayat (4) dalam Undang-Undang yang sama yang menyatakan bahwa: "peserta pemilihan dapat mengajukan permohonan pembatalan penetapan hasil penghitungan perolehan suara oleh KPU provinsi atau
KPU kabupaten/kota kepada Mahkamah Konstitusi”.

b) Tenggat waktu pengajuan permohonan keberatan pasangan calon terhadap surat keputusan KPU Provinsi atau Kabupaten/Kota mengenai penetapan hasil akhir perolehan suara dalam Pilkada (MK menggunakan istilah "tenggang waktu"). Mengenai tenggat waktu ini, MK mengacu pada Pasal 157 ayat (5) UU No 10/2016 dan Pasal 5 ayat (1) Peraturan MK 1/2016 sebagaimana telah diubah dengan Peraturan MK No 1/2017.

c) Legal standing pemohon untuk mengajukan permohonan dalam perkara perselisihan hasil Pilkada. Dasar hukum yang digunakan untuk memeriksa legal standing pemohon adalah Pasal 158 ayat (1) dan (2) UU No. 8/2015 dan Pasal 7 ayat (1) dan (2) Peraturan MK No 1/2016 sebagaimana diubah dengan Peraturan MK No $1 / 2017$.

d) Eksepsi termohon/pihak terkait dan pokok permohonan pemohon dalam perkara perselisihan hasil Pilkada. Dalam hal ini MK memeriksa pelanggaran yang menjadi dalil oleh para pemohon beserta buktibukti yang diajukan oleh pemohon untuk memperkuat pembuktian pelanggaranpelanggaran yang menjadi dalil.

Setelah memeriksa empat komponen pokok perkara di atas, MK mengambil keputusan yang pada umumnya untuk konteks Pilkada Serentak 2017 dapat dikelompokkan ke dalam 3 kategori utama putusan; 1) permohonan tidak dapat diterima, 2) permohonan ditolak sepenuhnya, dan 3) permohonan dikabulkan sebagian. Disamping itu, MK juga mengeluarkan beberapa putusan sela untuk dua perintah: 1) pemungutan suara, dan 2) lanjutan rekapitulasi suara.

Dalam perkara-perkara sengketa hasil Pilkada 2017 yang disidangkan oleh MK, sebagian besar permohonan tidak dapat diterima oleh MK. Dari 60 putusan yang dibacakan MK dalam sidang pembacaan putusan, 49 permohonan diputus dengan amar putusan permohonan tidak dapat diterima. Alasan di balik putusan tidak dapat diterima tersebut sepenuhnya karena alasan tidak memenuhi ketentuan UU No 10/2016 juncto 
PMK No 1/2016, sebagaimana diubah dengan Peraturan MK No 1/2017. Sebagian besar yaitu 37 permohonan tidak dapat diterima dengan alasan tidak memiliki legal standing karena selisih suara pemohon melebihi persentase yang ditetapkan UU dan Peraturan MK. Sedangkan 11 permohonan lainnya tidak diterima karena melewati tenggat waktu yang disediakan oleh pedoman beracara perselisihan hasil pemilihan yaitu 3 x 24 jam kerja. Satu perkara lainnya, yaitu sengketa Pilkada Kota Jayapura, tidak dapat diterima karena alasan keduanya; melewati tenggat waktu dan melebihi persentase selisih suara.

Lima putusan menyatakan menolak permohonan pemohon untuk seluruhnya. Putusan pada kategori ini terjadi untuk perkara sengketa hasil Pilkada di Kabupaten Takalar, Kota Salatiga, Kabupaten Bombana, Kota Yogyakarta, dan Provinsi Sulawesi Barat. Penolakan permohonan tersebut disebabkan oleh pelanggaran yang menjadi dalil pemohon tidak dikuatkan dengan buktibukti yang beralasan menurut hukum dan/atau bukti-bukti yang diajukan tidak relevan dengan pembuktian pelanggaran yang menjadi dalil pemohon.

Hanya satu perkara dimana permohonan pemohon dikabulkan oleh MK untuk sebagian. Permohonan tersebut terkait dengan perselisihan hasil Pilkada di Kabupaten Intan Jaya. MK mengabulkan permohonan Pemohon untuk sebagian. Oleh karena itu MK menyatakan batal Keputusan Komisi Pemilihan Umum Kabupaten Intan Jaya Nomor 16/Kpts/KPU-IJ/IV/2017 tentang Penetapan Pembatalan Surat Keputusan Komisi Pemilihan Umum Kabupaten Intan Jaya Nomor 14/Kpts/KPU-IJ/IV/2017 Penetapan Rekapitulasi Hasil Penghitungan Suara Dalam Pemilihan Bupati dan Wakil Bupati Intan Jaya Tahun 2017, bertanggal 20 April 2017. Selanjutnya, MK menyatakan batal Surat Keputusan Komisi Pemilihan Umum Kabupaten Intan Jaya Nomor 14/Kpts/KPU-IJ/IV/2017 tentang Penetapan Rekapitulasi Hasil Penghitungan Suara Dalam Pemilihan Bupati dan Wakil Bupati Intan Jaya Tahun 2017, bertanggal 20 April 2017, sepanjang perolehan suara pada 7 (tujuh) TPS yaitu: 1) TPS 1, TPS 2, TPS 3, dan TPS 4 Kampung Emondi, Distrik Sugapa; dan 2) TPS 1 Kampung Soali, TPS 2 Kampung Unabundoga, dan TPS 1 Kampung Tausiga, Distrik Agisiga. Maka MK memerintahkan kepada Komisi Pemilihan Umum Provinsi Papua untuk melakukan Pemungutan Suara Ulang Pemilihan Bupati dan Wakil Bupati Kabupaten Intan Jaya Tahun 2017 di 7 (tujuh) TPS yaitu: 1) TPS 1, TPS 2, TPS 3, dan TPS 4 Kampung Emondi, Distrik Sugapa; dan 2) TPS 1 Kampung Soali, TPS 2 Kampung Unabundoga, dan TPS 1 Kampung Tausiga, Distrik Agisiga; dalam jangka waktu paling lama 30 (tiga puluh) hari kerja setelah putusan ini diucapkan.

Empat kasus lainnya diputus dalam putusan sela untuk dilakukannya pemungutan suara ulang. Pemungutan suara ulang ini kemudian menghasilkan hasil pemilihan yang tidak memancing permohonan gugatan perkara baru. Sedangkan dalam satu kasus lainnya, MK memerintahkan pemungutan suara ulang yang kemudian diakhiri dengan putusan permohonan tidak dapat diterima, karena hasil pemungutan suara ulang ternyata menghasilkan persentase selisih suara yang melebihi ketentuan peraturan perundangundangan sebagai dasar bagi kedudukan hukum pemohon.

Dengan hasil analisis putusan yang sudah dipaparkan di atas, dapat dikatakan bahwa MK sesungguhnya telah berkinerja cukup baik dalam penegakan keadilan prosedural dalam pemeriksaan perkara-perkara perselisihan Pilkada serentak tahun 2017. MK sepenuhnya konsisten untuk menjadikan pasal mengenai tenggat waktu pengajuan permohonan dan kedudukan hukum pemohon sebagai batu uji apakah sebuah permohonan sengketa Pilkada dapat dilanjutkan atau tidak. Hal itu sebagai dampak dari diadopsinya proses dismissal (dismissal process) yang biasa digunakan dalam Pengadilan Tata Usaha Negara.

Dismissal process merupakan pekerjaan hakim untuk meneliti, memilah gugatan yang masuk ke pengadilan. Proses ini merupakan konsekuensi dari asas ius curia novit/curia novit jus, sehingga pengadilan atau hakim tidak boleh menolak perkara (sebagaimana diadopsi dalam ketentuan Pasal 10 Undang- 
Undang Nomor 48 Tahun 2009 tentang Kekuasaan Kehakiman (UU Kekuasaan Kehakiman). Hakim harus tetap memeriksa meskipun sejak awal sesungguhnya perkara tersebut tidak layak untuk diperkarakan, karena tidak memenuhi syarat formal maupun syarat materiel.

Dismissal process merupakan keputusan dalam bentuk penetapan hakim yang diputuskan dalam suatu rapat musyawarah yang secara khusus dilakukan untuk itu, yang dilengkapi pertimbangan hukum bahwa gugatan yang diajukan ke pengadilan dinyatakan tidak dapat diterima atau tidak berdasar. Putusan tersebut menurut Peraturan MK No 1/2016 yang telah diubah dengan Peraturan MK No 1/2017 menyatakan bahwa putusan dismissal tersebut diambil dalam sebuah sidang pleno atau panel yang dihadiri oleh Sembilan hakim atau dalam situasi sangat khusus dihadiri minimal tujuh hakim konstitusi.

Dismissal process akan menentukan permohonan dalam suatu perkara dapat dilanjutkan atau sebaliknya permohonan tidak dapat diterima. Syarat-syarat tersebut terutama terkait hal-hal formal seperti kedudukan hukum para pihak (legal standing), tenggat waktu pengajuan gugatan, syarat persentase selisih perolehan suara berdasarkan ketentuan peraturan perundangundangan. Mekanisme dismissal process tersebut secara substantif merupakan mekanisme untuk menyaring di level sangat dini seluruh gugatan yang masuk. Dengan adanya dismissal process tersebut kerja-kerja MK dalam menyidangkan gugatan sengketa Pilkada yang potensial berjumlah lebih dari ratusan menjadi lebih sederhana. Hakim MK yang hanya berjumlah Sembilan orang tidak akan terlalu kewalahan dalam memeriksa sengketa Pilkada. Dalam konteks itu, untuk mengurangi beban MK, agar MK dapat mengoptimalkan peran dan peranannya dalam melaksanakan kewenangan konstitusional intinya, menjadi sangat mendesak untuk menyegerakan pembentukan badan peradilan khusus pemilihan umum sebagaimana menjadi original intent pembentuk UU di lembaga legislatif.
Penegakan keadilan prosedural dalam peradilan sengketa Pilkada tidak secara serta in line dengan perwujudan keadilan elektoral yang bersifat substantif. Dalam perspektif keadilan substantif, hakim harus berani berijtihad diluar ketentuan undang-undang agar keadilan bisa ditemukan sebagai pertimbangan dasar dalam putusan. Dalam konteks itu, keadilan substantif merupakan keadilan yang diciptakan oleh hakim dalam putusan-putusannya berdasar hasil eksplorasi dan elaborasi hakim terhadap rasa keadilan di dalam masyarakat, tanpa terbelenggu bunyi pasal undang-undang yang berlaku. Bentuk perbuatan yang sama bisa divonis secara berbeda, tergantung pada hasil penggalian hakim atas rasa keadilan. Sebab hakim adalah pengadil, bukan penghukum. Itulah makna judge makes law (hakim membuat hukum). Keadilan substantif (substantive justice) seringkali dikontraskan dengan keadilan prosedural (procedural justice), yakni putusan hakim atau proses penegakan hukum yang sepenuhnya didasarkan pada bunyi undang-undang (Mahfud-MD, 2014).

Melihat putusan-putusan yang dikeluarkan, ada kecenderungan bahwa putusan dismissal yang dilakukan oleh MK cenderung mengabaikan keadilan substantif. Ada dua hal yang potensial membuat prosedur beracara tidak dapat mewujudkan keadilan substantif dalam proses peradilan sengketa Pilkada di MK. Pertama, mengenai tenggat waktu. Melalui putusan dismissal, MK telah memutus bahwa sebelas permohonan pemohon dalam sengketa Pilkada serentak tahun 2017 dinyatakan tidak dapat diterima karena melewati tenggat waktu yang ditetapkan undang-undang mengenai Pilkada dan Peraturan MK tentang Pedoman Beracara Perselisihan Hasil Pilkada. Satu lainnya karena melewati tenggat waktu sekaligus karena pemohon tidak memiliki kedudukan hukum. Sebagaimana disampaikan di awal, putusan ini diatur dalam pedoman beracara atau hukum formal sengketa hasil Pilkada.

Menyamakan keseluruhan daerah di Indonesia, kota dan desa, sentral dan ferifer dalam soal akses, lalu lintas manusia dan barang dengan konfigurasi alam dan kemampuan sumber daya sekaligus 
ketersediaan infrastruktur transportasi yang ada sungguh sebuah regulasi yang tidak memenuhi keadilan secara substantif. Maka wajar jika banyak permohonan yang tidak dapat dilanjutkan hanya karena putusan MK memutuskan permohonan sudah melewati tenggat waktu.

Padahal dalam doktrin hukum tata negara ada prinsip dalam asas gugatan dalam pemilu yaitu nunc pro tunc. Dalam kasus memperebutkan kursi hakim di Beaver Country, Pennsylvania, antara Zupsic dan Lauglin. Zupsic mengajukan gugatan pemilu nunc pro tunc, pengadilan menerimanya, karena setelah batas waktu yang ditentukan undang-undang baru ditemukan indikasi kecurangan (Weinberg, 2008).

Menyelisik undang-undang pemilihan gubernur, bupati dan walikota tidak ditemukan ketentuan bahwa gugurnya batas waktu jika ditemukan bukti baru telah terjadi kesalahan atau pelanggaran atau kejahatan dalam pemilihan. Jika mengadopsi prinsip nunc pro tunc maka ketika tenggat waktu pengajuan sudah habis, perkara masih bisa diterima Mahkamah karena adanya bukti baru.

Kedua, soal persentase selisih hasil suara dalam sengketa Pilkada 2017. Ketentuan undang-undang Pilkada dan peraturan MK menegaskan persentase selisih yang dapat diajukan permohonan kepada MK. Sebagaimana diatur dalam udang-undang Pilkada dan peraturan MK di atas.

Untuk tingkat provinsi, peserta pemilihan gubernur dan wakil gubernur dapat mengajukan permohonan pembatalan penetapan hasil penghitungan suara dengan ketentuan:

a. provinsi dengan jumlah penduduk sampai dengan 2.000.000 (dua juta) jiwa, pengajuan perselisihan perolehan suara dilakukan jika terdapat perbedaan paling banyak sebesar $2 \%$ (dua persen) dari total suara sah hasil penghitungan suara tahap akhir yang ditetapkan oleh KPU provinsi;

b. provinsi dengan jumlah penduduk lebih dari 2.000.000 (dua juta) sampai dengan 6.000.000 (enam juta), pengajuan perselisihan perolehan suara dilakukan jika terdapat perbedaan paling banyak sebesar
1,5\% (satu koma lima persen) dari total suara sah hasil penghitungan suara tahap akhir yang ditetapkan oleh KPU provinsi;

c. provinsi dengan jumlah penduduk lebih dari 6.000.000 (enam juta) sampai dengan 12.000.000 (dua belas juta) jiwa, pengajuan perselisihan perolehan suara dilakukan jika terdapat perbedaan paling banyak sebesar $1 \%$ (satu persen) dari total suara sah hasil penghitungan suara tahap akhir yang ditetapkan oleh KPU provinsi; dan

d. provinsi dengan jumlah penduduk lebih dari 12.000.000 (dua belas juta) jiwa, pengajuan perselisihan perolehan suara dilakukan jika terdapat perbedaan paling banyak sebesar 0,5\% (nol koma lima persen) dari total suara sah hasil penghitungan suara tahap akhir yang ditetapkan oleh KPU provinsi.

Sedangkan pada pemilihan tingkat kabupaten/kota, peserta pemilihan bupati dan wakil bupati serta walikota dan wakil walikota dapat mengajukan permohonan pembatalan penetapan hasil penghitungan perolehan suara dengan ketentuan:

a. kabupaten/kota dengan jumlah penduduk sampai dengan 250.000 (dua ratus lima puluh ribu) jiwa, pengajuan perselisihan perolehan suara dilakukan jika terdapat perbedaan paling banyak sebesar $2 \%$ (dua persen) dari total suara sah hasil penghitungan suara tahap akhir yang ditetapkan oleh KPU Kabupaten/Kota;

b. kabupaten/kota dengan jumlah penduduk lebih dari 250.000 (dua ratus lima puluh ribu) jiwa sampai dengan 500.000 (lima ratus ribu) jiwa, pengajuan perselisihan perolehan suara dilakukan apabila terdapat perbedaan paling banyak sebesar $1,5 \%$ (satu koma lima persen) dari total suara sah hasil penghitungan suara tahap akhir yang ditetapkan oleh KPU Kabupaten/Kota;

c. kabupaten/kota dengan jumlah penduduk lebih dari 500.000 (lima ratus ribu) jiwa sampai dengan 1.000.000 (satu juta) jiwa, pengajuan perselisihan perolehan suara dilakukan jika terdapat perbedaan paling banyak sebesar 1\% (satu persen) dari total suara sah hasil penghitungan suara tahap akhir KPU Kabupaten/Kota; dan 
d. kabupaten/kota dengan jumlah penduduk lebih dari 1.000.000 (satu juta) jiwa, pengajuan perselisihan perolehan suara dilakukan jika terdapat perbedaan paling banyak sebesar 0,5\% (nol koma lima persen) dari total suara sah hasil penghitungan suara tahap akhir KPU Kabupaten/Kota.

Dengan berdasar pada ketentuan mengenai ambang batas selisih suara dalam pengajuan permohonan ke MK, pada kenyataannya kemudian MK menyatakan bahwa 37 permohonan dinyatakan tidak diterima, dan satu lainnya juga tidak bisa diterima dengan alasan yang sama plus alasan melewati tenggat waktu pengajuan permohonan.

Apa yang diatur dalam ketentuan tersebut mengindikasikan bahwa salah satu cara yang paling bisa diandalkan bagi para pasangan calon dalam Pilkada adalah memastikan bahwa kemenangan yang diraih melampaui selisih, $0,5 \%, 1 \%, 1,5 \%$, atau $2 \%$ dari pasangan calon kompetitor, termasuk jika hal itu dicapai dengan kecurangan, terutama kecurangan yang tidak bersifat terstruktur, sistematis, dan massif. Sebab dengan selisih suara lebih dari persentase tersebut, dapat dipastikan pasangan calon yang kalah "dengan sendirinya" akan dianggap tidak memiliki legal standing oleh panel hakim Mahkamah Konstitusi, sehingga permohonan mereka akan dinyatakan tidak dapat diterima. Maka dengan sendirinya, substansi kecurangan yang dilakukan oleh pasangan calon yang meraih selisih suara besar tidak akan diperiksa dalam persidangan sengketa Pilkada di MK.

Praktik MK yang memprioritaskan untuk menghitung selisih suara dibandingkan menggali hal-hal lebih substantif dari permohonan para pemohon menyederhanakan fungsi MK menjadi sekadar "mahkamah kalkulator" (Junaidi, 2013). MK lebih banyak melihat perselisihan hasil Pilkada sebagai persoalan perbedaan angka-angka perolehan suara. Jadi perkara sengketa Pilkada disederhanakan pada soal kalkulasi siapa lebih unggul berapa persen dari siapa. Dengan demikian, MK menihilkan persoalan

pelanggaran-pelanggaran substansial yang mungkin terjadi di balik berapa pun persentase kekalahan Pemohon.

Dua catatan mengenai problem penegakan keadilan substantif di atas mengindikasikan bahwa dismissal process yang dilakukan oleh MK dengan memeriksa tenggat waktu dan persentase selisih suara sejatinya menunjukkan bahwa MK lebih memilih untuk melempar tanggung jawab penegakan keadilan substantif kepada proses legislasi DPR daripada penggalian hukum sendiri. Padahal keadilan substantif, seharusnya lebih bisa ditegakkan hakim konstitusi dengan menggali dan menemukan hukum sendiri untuk menegakkan keadilan yang lebih hakiki bagi para pihak, dimana hal itu hanya mungkin dilakukan dengan memeriksa substansi permohonan dan pelanggaran-pelanggaran yang mungkin terjadi dan menyebabkan kandidat terbaik dalam sebuah perhelatan elektoral tidak mendapat kesempatan untuk menjadi pemimpin dalam sebuah tata demokrasi konstitusional.

\section{Simpulan}

MK sesungguhnya telah berkinerja cukup baik untuk menegakkan keadilan prosedural dalam pemeriksaan perkara-perkara perselisihan Pilkada serentak tahun 2017. MK sepenuhnya konsisten untuk menjadikan pasal mengenai tenggat waktu pengajuan permohonan dan kedudukan hukum pemohon sebagai batu uji mengenai dapat diterima atau tidaknya sebuah permohonan dalam perkara sengketa Pilkada 2017. Hal itu sebagai dampak dari diadopsinya proses dismissal (dismissal process), yaitu pekerjaan hakim untuk meneliti, memilah gugatan yang masuk ke pengadilan sebagai konsekuensi dari asas ius curia novit/curia novit jus, sehingga pengadilan atau hakim tidak boleh menolak perkara. Kedua, penegakan keadilan prosedural dalam peradilan sengketa Pilkada oleh MK tidak secara serta merta in line dengan perwujudan keadilan elektoral yang bersifat substantif. Ada kecenderungan bahwa putusan dismissal yang dilakukan oleh MK cenderung mengabaikan keadilan substantif. Ada dua hal yang potensial membuat prosedur beracara tidak dapat mewujudkan keadilan 
substantif dalam proses peradilan sengketa Pilkada yakni mengenai tenggat waktu dan mengenai persentase selisih hasil suara dalam sengketa.

\section{Ucapan Terima Kasih}

Terima kasih disampaikan pada Fakultas Ilmu Sosial yang telah memberikan kesempatan para penulis untuk melakukan penelitian ini melalui dana DIPA FIS tahun anggaran 2018.

\section{Referensi}

Akbar, I. (2016). Pilkada serentak dan geliat dinamika politik dan pemerintahan lokal Indonesia. Jurnal Ilmu Pemerintahan, 2(1), 95-110.

Arikunto, S. (2013). Prosedur penelitian. Suatu pendekatan praktek (15 ed.). Jakarta: Rineka Cipta.

Bass, K., \& Choudhry, S. (2013). Constitutional review in new democracies.

Heywood, A. (2013). Politics (Fourth). UK: Palgrave Macmillan.

Junaidi, V. (2013). Mahkamah Konstitusi bukan mahkamah kalkulator. Jakarta: Themis Books.

Krippendorff, K. (2004). Content analysis. An introduction to its methodology (2 ed.). Thousand Oaks, California: Sage Publications, Inc. https://doi.org/10.2307/2288384

Mahfud-MD, M. (2009). The role of the constitutional court in the development of democracy in Indonesia. In World Conference on Constitutional Justice", Cape Town, January.

Mahfud-MD, M. (2014, Agustus 30). Keadilan substantif. Koran Sindo.

Mahkamah Konstitusi. (2018). Rekapitulasi perkara perselisihan hasil pemilihan umum kepala daerah dan wakil kepala daerah | Mahkamah Konstitusi RI.

Orozco-Henríquez, J. (2010). Electoral justice: The international IDEA Handbook. Stockholm: International Institute for Democracy and Electoral Assistance (IDEA).

Weinberg, B. H. (2008). The resolution of election disputes legal principles that control election challenges (2 ed.).
Washington, D.C: IFES.

Zoelva, H. (2013). Problematika penyelesaian sengketa hasil pemilukada oleh Mahkamah Konstitusi. Jurnal Konstitusi, 10(3), 378-398. 